Correspondence

Fabiano L. Thompson

Fabiano.Thompson@rug.ac.be

\title{
Vibrio kanaloae sp. nov., Vibrio pomeroyi sp. nov. and Vibrio chagasii sp. nov., from sea water and marine animals
}

\author{
F. L. Thompson, ${ }^{1,2}$ C. C. Thompson, ${ }^{1,2}$ Y. Li, ${ }^{3}$ B. Gomez-Gil, ${ }^{4}$ \\ J. Vandenberghe, ${ }^{1}$ B. Hoste ${ }^{2}$ and J. Swings ${ }^{1,2}$ \\ 1,2 Laboratory for Microbiology ${ }^{1}$ and $\mathrm{BCCM}^{\mathrm{TM}} / \mathrm{LMG}$ Bacteria Collection${ }^{2}$, Ghent University, \\ K. L. Ledeganckstraat 35, Ghent 9000, Belgium \\ ${ }^{3}$ College of Marine Life Sciences, Ocean University of Qingdao, 5 Yushan Road, Oingdao \\ 266003, China \\ ${ }^{4}$ CIAD/Mazatlán Unit for Aquaculture, AP. 711, Mazatlán, Sinaloa, Mexico 82000
}

\begin{abstract}
The taxonomic position of the fluorescent amplified fragment length polymorphism fingerprinting groups A46 (five isolates), A51 (six isolates), A52 (five isolates) and A53 (seven isolates) obtained in a previous study were further analysed through a polyphasic approach. The 23 isolates were phylogenetically related to Vibrio splendidus, but DNA-DNA hybridization experiments proved that they belong to three novel species. Chemotaxonomic and phenotypic analyses further disclosed several features that differentiate between the 23 isolates and known Vibrio species. The names Vibrio kanaloae sp. nov. (type strain LMG $20539^{\top}=$ CAIM $485^{\top}$; EMBL accession no. AJ316193; $\mathrm{G}+\mathrm{C}$ content $44 \cdot 7 \mathrm{~mol} \%$ ), Vibrio pomeroyi sp. nov. (type strain LMG $20537^{\top}=\mathrm{CAIM} 578^{\top}$; EMBL accession no. AJ491290; G + C content 44.1 mol\%) and Vibrio chagasii sp. nov. (type strain LMG $21353^{\top}=$ CAIM $431^{\top} ;$ EMBL accession no. AJ316199; $\mathrm{G}+\mathrm{C}$ content $44.6 \mathrm{~mol} \%$ ) are respectively proposed to encompass the five isolates of $A 46$, the six isolates of $A 51$ and the 12 isolates of A52/A53. The three novel species can be distinguished from known Vibrio species by several phenotypic features, including utilization and fermentation of various carbon sources, $\beta$-galactosidase activity and fatty acid content (particularly of $12: 0,14: 0,14: 0$ iso and $16: 0$ iso).
\end{abstract}

\section{INTRODUCTION}

Several Vibrio species are ubiquitous in aquatic ecosystems and display an extraordinarily high growth rate, which makes them highly successful and dominant, particularly in eutrophic environments (Aiyar et al., 2002; Macián et al.,

Published online ahead of print on 4 October 2002 as DOI 10.1099/ ijs.0.02490-0.

Abbreviation: FAFLP, fluorescent amplified fragment length polymorphism.

The GenBank/EMBL/DDBJ accession numbers for the 16S rDNA sequences of strains LMG 20539', LMG 21522, LMG 21523, LMG 21353', LMG 13237, LMG 21354, LMG 20537', LMG 21351 and LMG 21352 are respectively AJ316193, AJ490153, AJ490154, AJ316199, AJ490157, AJ490158, AJ491290, AJ316197 and AJ490152.

Results of repetitive extragenic palindrome-PCR fingerprinting of $V$. kanaloae, $V$. pomeroyi, $V$. chagasii and the most closely related Vibrio species and variable features/differentiating characteristics for $V$. kanaloae, $V$. pomeroyi and $V$. chagasii are available as supplementary data in IJSEM Online.
2000). In this study, we report on the taxonomic analysis of four unidentified groups of vibrios, A46 (five isolates), A51 (six isolates), A52 (seven isolates) and A53 (five isolates), found previously (Thompson et al., 2001). These isolates were phylogenetically related to Vibrio splendidus, a ubiquitous luminous marine bacterium that was first described by the early microbial ecologist Beijerinck in 1900. V. splendidus strains have consistently been found in association with cultured oysters (Ostrea edulis) in the Mediterranean Sea over the years, suggesting a close relationship between the bacterium and the host invertebrate (Macián et al., 2000). V. splendidus has also been implicated as an aetiological agent of septicaemia in various species of fish (Austin \& Austin, 1999) and as the causative agent of bacillary necrosis of oyster larvae (Sugumar et al., 1998). Our polyphasic taxonomic study, including genomic, phenotypic and chemotaxonomic analyses, revealed that the 23 isolates belong to three novel species, for which we propose the names Vibrio kanaloae sp. nov., Vibrio pomeroyi sp. nov. and Vibrio chagasii sp. nov. V. kanaloae was found to be ubizquitous in the aquatic environment, whereas 
Table 1. Strains studied

Strains prefixed $\mathrm{R}$ and VIB are respectively held in the Research Collection and the Vibrio Collection at the BCCM/LMG Bacteria Collection.

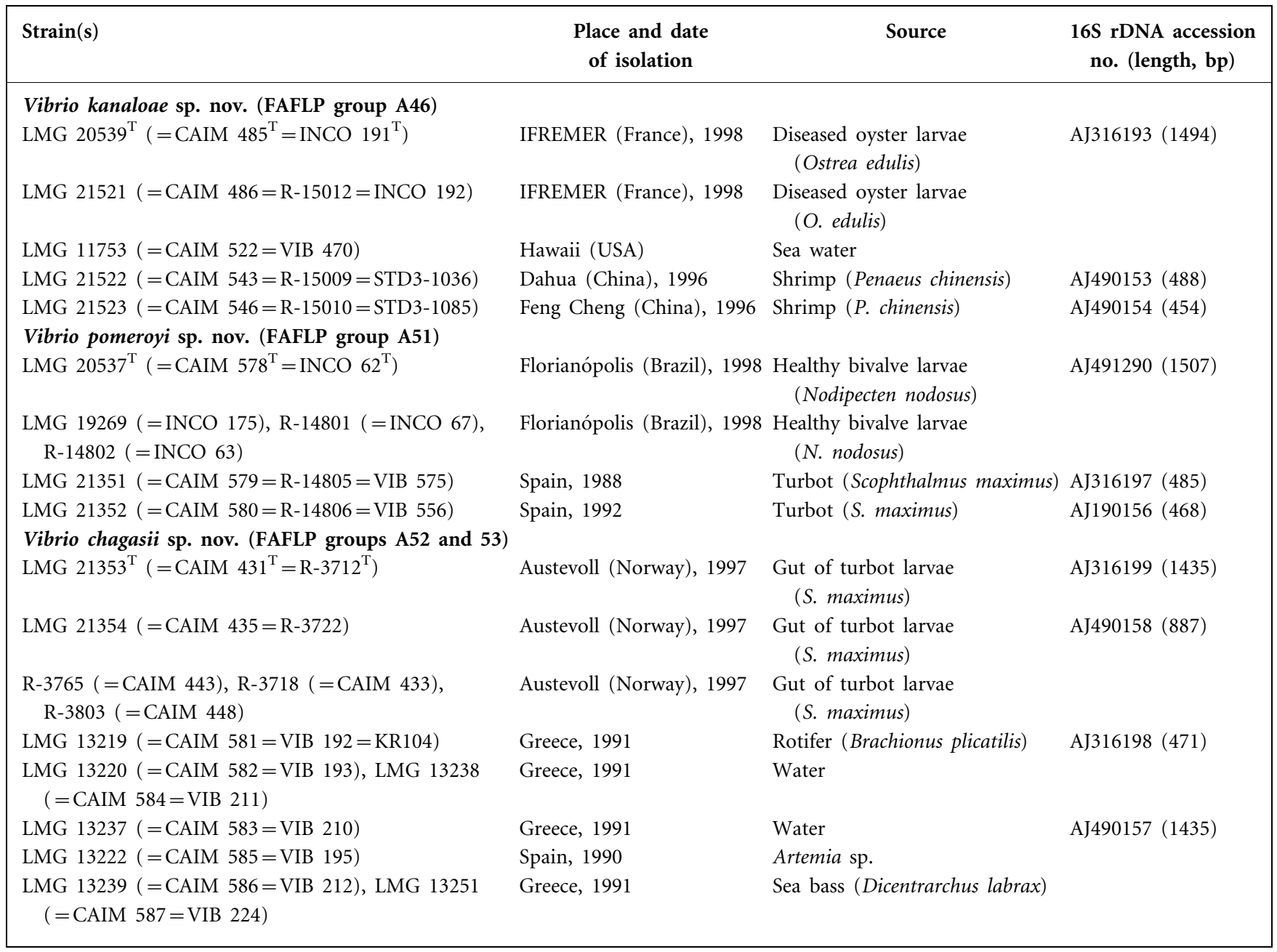

$V$. pomeroyi isolates were abundant in cultures of Nodipecten nodosus larvae in the south of Brazil. V. chagasii isolates were found to be regular inhabitants of rotifer cultures in Greece (Verdonck et al., 1997).

\section{METHODS}

Bacterial strains, growth conditions and DNA isolation. Strains used in this study are listed in Table 1. Strains were grown aerobically on tryptone soy agar (TSA; Oxoid) supplemented with $2 \%$ (w/v) $\mathrm{NaCl}$ for $24 \mathrm{~h}$ at $28{ }^{\circ} \mathrm{C}$. DNA was extracted by following the methodology described by Pitcher et al. (1989). All strains included in this study were deposited in the BCCM/LMG Bacteria Collection at Ghent University and in the Collection of Aquacultural Important Micro-organisms (CAIM) of the Centre for Research on Nutrition and Development in Mazatlán, Mexico.

Genotypic analyses. Selective amplification of restriction fragments, using fluorescent amplified fragment length polymorphism (FAFLP), and determination of almost-complete 16S rDNA sequences were accomplished essentially as described previously (Thompson et al., 2001). Alignment of the $16 \mathrm{~S}$ rDNA sequences, distance estimations (Jukes \& Cantor, 1969), clustering by neighbour-joining (Saitou \& Nei, 1987), maximum-likelihood and maximum-parsimony methods and stability of the clusters (bootstrap analysis with 1000 replicates) were performed with the software BioNumerics 2.5 (Applied Maths). Repetitive extragenic palindrome-PCR fingerprinting was performed essentially as described previously (Sawabe et al., 2002). DNA-DNA hybridization experiments using photobiotinlabelled DNAs were run under stringent conditions $\left(39{ }^{\circ} \mathrm{C}\right)$ by following the methodology described by Willems et al. (2001). Hybridizations were performed on four replicates. Each DNA relatedness value is the mean of reciprocal and non-reciprocal reactions. The $\mathrm{G}+\mathrm{C}$ content (mol\%) of DNA was determined by using HPLC (Mesbah et al., 1989).

Phenotypic analyses. Phenotypic characterization of the isolates was performed using API 20E and API ZYM (bioMérieux) and BIOLOG GN metabolic fingerprinting according to the instructions of the manufacturers, with slight modifications (Thompson et al., 2002). Classical phenotypic tests were performed as described previously (Baumann et al., 1984; Farmer \& Hickman-Brenner, 1992; Murray et al., 1994; Thompson et al., 2002; Vandamme et al., 1998). Antibiograms were carried out using disc-diffusion methodology (Acar \& Goldstein, 1996) with commercial discs (Oxoid). The inhibition zone of each antibiotic was measured on strains grown on 


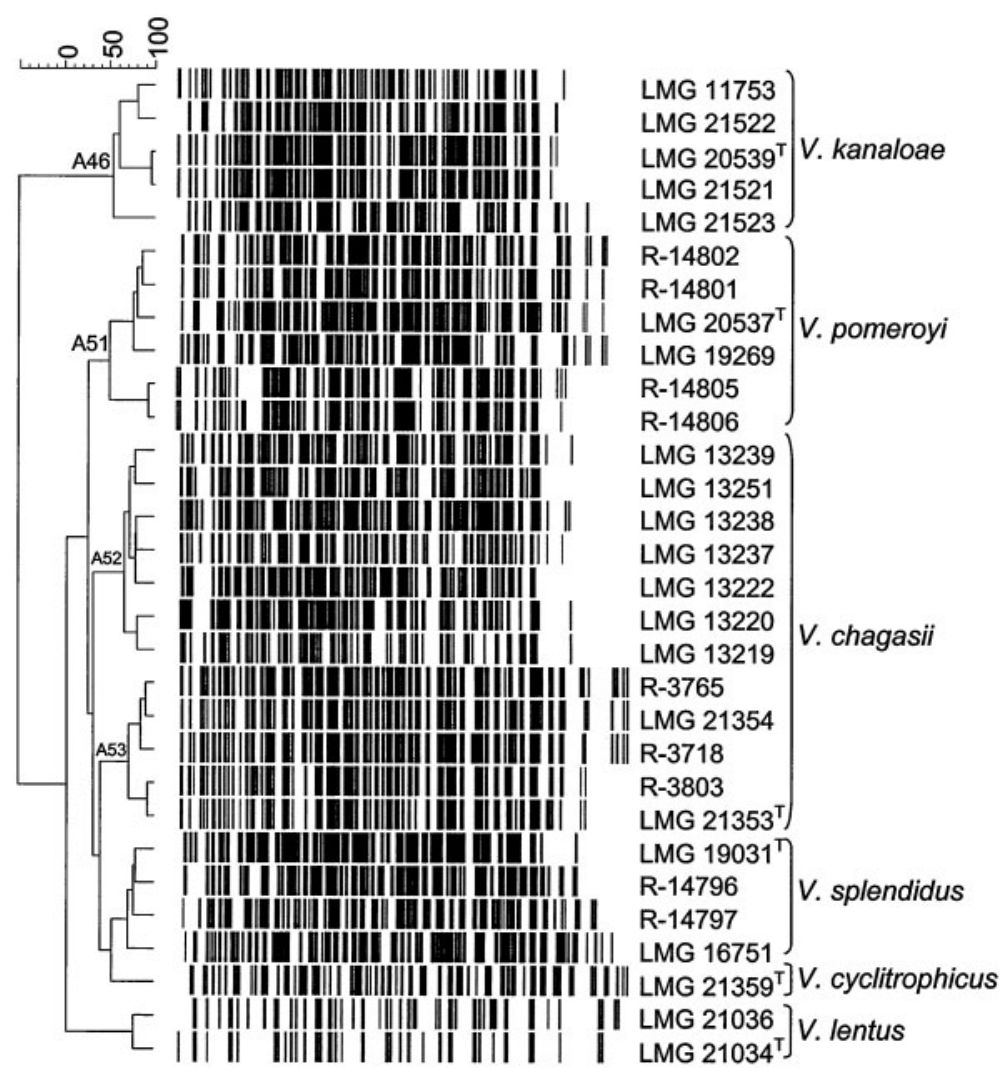

Fig. 1. Dendrogram of the FAFLP patterns of Vibrio kanaloae sp. nov. $(n=5)$, Vibrio pomeroyi sp. nov. $(n=6)$ and Vibrio chagasii sp. nov. $(n=12)$. V. splendidus, V. cyclitrophicus and $V$. lentus were included as outgroups. A band-based (Dice) cluster analysis (Ward) was used.

Iso-sensitest agar (Oxoid) supplemented with $1.5 \%(\mathrm{w} / \mathrm{v}) \mathrm{NaCl}$ for $24 \mathrm{~h}$ at $28{ }^{\circ} \mathrm{C}$. Fatty acid methyl ester analysis was carried out as described by Huys et al. (1994). Isolates were grown on trypticase soy broth (Becton Dickinson) supplemented with $1.5 \%$ (w/v) Bacto agar (Becton Dickinson) and $1.5 \%(\mathrm{w} / \mathrm{v}) \mathrm{NaCl}$ at $28{ }^{\circ} \mathrm{C}$ for $24 \mathrm{~h}$. Approximately $50 \mathrm{mg}$ cells was harvested and the fatty acids were isolated, according to the recommendations of the manufacturer, using the Microbial Identification System manual and software, version 3.9 (Microbial ID).

\section{RESULTS AND DISCUSSION}

The FAFLP patterns of groups A46, A51 and A52/A53 consisted of $116 \pm 19,126 \pm 11$ and $119 \pm 14$ bands, respectively, and were clearly different from those of their closest phylogenetic neighbours (Fig. 1) and from other known Vibrio species (Thompson et al., 2001). Isolates of groups A46, A51 and A52/A53 had mutual pairwise similarities of at least $57 \cdot 2,72 \cdot 2$ and $60 \%$, respectively. Representative strains of each FAFLP group were also distinguishable from other closely related Vibrio species on the basis of repetitive chromosomal element analysis (available as supplementary data in IJSEM Online).

The 16S rDNA sequences of at least three representative isolates of each FAFLP group were determined (Table 1). FAFLP group A46 (LMG 20539 ${ }^{\mathrm{T}}$, LMG 21522, LMG 21523), FAFLP group A51 (LMG 20537 ${ }^{\mathrm{T}}$, LMG 21351, LMG 21352) and FAFLP groups A52 and A53 (LMG 21353 ${ }^{\mathrm{T}}$, LMG 13237, LMG 21354, LMG 13219) were allocated to the genus Vibrio by the FASTA program (Pearson \& Lipman, 1988). The $16 \mathrm{~S}$
rDNA sequence similarity within each FAFLP group was $\geqslant 99 \%$. Isolates LMG 20539 ${ }^{\mathrm{T}}$, LMG 21522 and LMG 21523 shared $99.5 \%$ 16S rDNA similarity, while LMG $20537^{\mathrm{T}}$, LMG 21351 and LMG 21352 shared 99.4\%. Isolates LMG

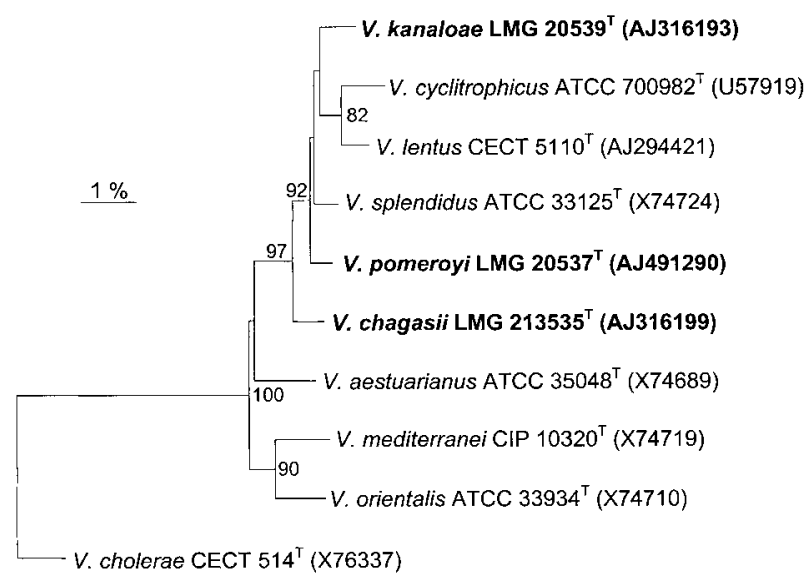

Fig. 2. Phylogenetic tree, with the estimated positions of Vibrio kanaloae sp. nov., Vibrio pomeroyi sp. nov. and Vibrio chagasii sp. nov., produced by using the neighbour-joining method based on almost-complete 16S rDNA sequences. Bootstrap values ( $>50 \%$ ) after 1000 simulations are shown. Bar, $1 \%$ estimated sequence divergence. 
Table 2. DNA-DNA binding percentages and $\mathrm{G}+\mathrm{C}$ contents of Vibrio strains examined

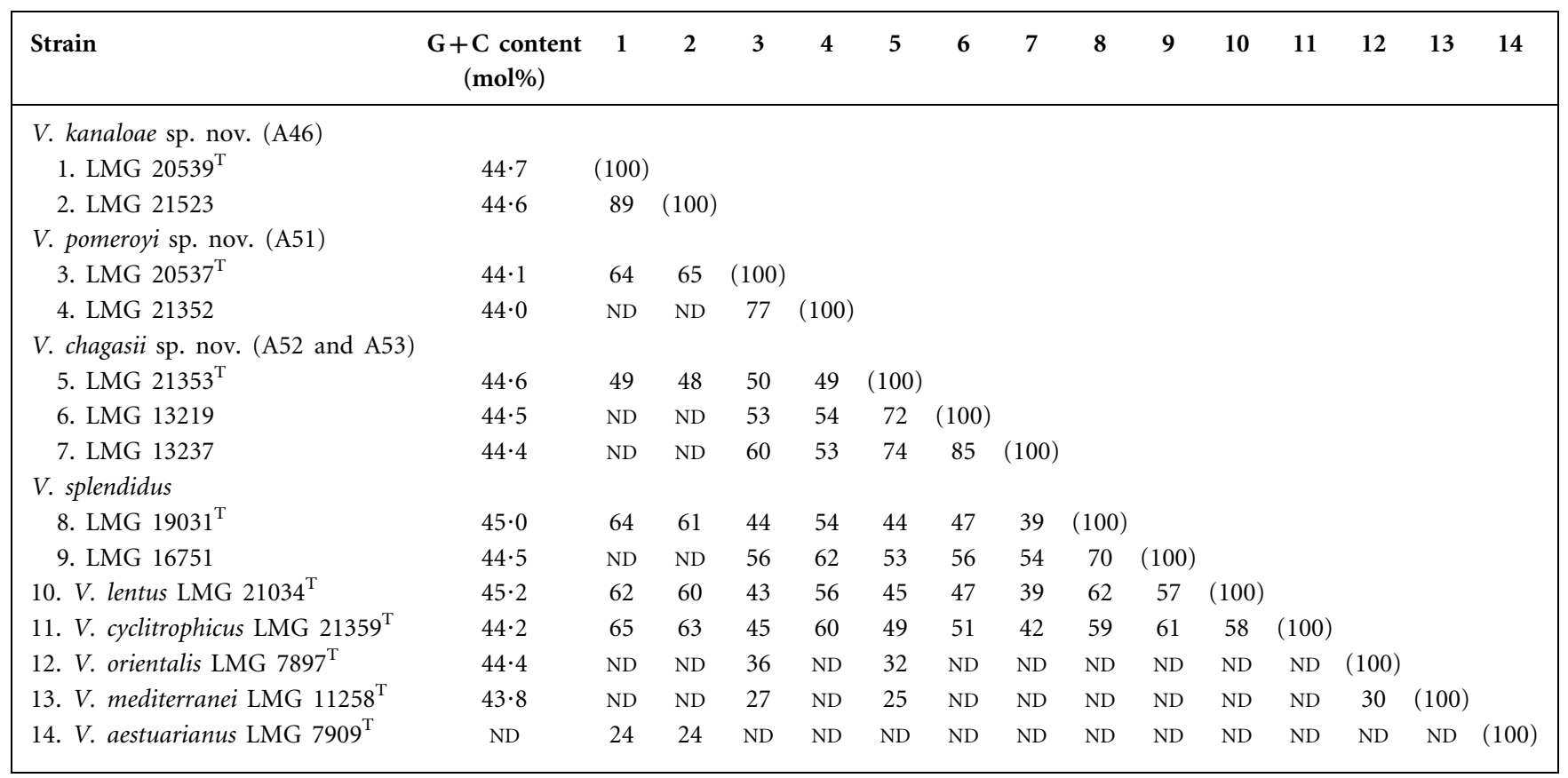

ND, Not determined.

$21353^{\mathrm{T}}$ and LMG 13237 showed $99 \cdot 7 \%$ similarity. The similarity between representative isolates of each FAFLP group was at least $97 \cdot 4 \%$. Phylogenetic trees based on almost-complete sequences and using neighbour-joining, maximum-likelihood and maximum-parsimony methods were all in agreement and revealed that the three novel Vibrio species are closely related to $V$. splendidus (respectively $98 \cdot 0,99 \cdot 1$ and $98 \cdot 5 \%$ similarity), Vibrio lentus $(97 \cdot 8$, $98 \cdot 4$ and $98 \cdot 2 \%)$, Vibrio cyclitrophicus $(97 \cdot 0,98 \cdot 3$ and $97 \cdot 7 \%)$, Vibrio mediterranei $(95 \cdot 7,97 \cdot 2$ and $97 \cdot 8 \%)$ and Vibrio orientalis $(96 \cdot 0,97 \cdot 1$ and $97 \cdot 6 \%$ ) (Fig. 2). The $16 \mathrm{~S}$ rDNA similarity of the three novel species towards other Vibrio species and other genera of the family Vibrionaceae was below 97 and below $93.5 \%$, respectively.

At least two representative isolates of each FAFLP group were chosen for DNA-DNA hybridization experiments. The isolates of A46, A51 and A52/A53 had 89, 77 and $72 \%$ mutual DNA-DNA relatedness, respectively, but $\leqslant 65 \%$ with other Vibrio species. Thus, these results confirm their status as novel species (Table 2). DNA hybridization experiments further confirmed that the three novel species and other Vibrio species in the same phylogenetic branch have intermediate DNA-DNA relatedness. Macián et al. (2001) have already demonstrated that $V$. lentus and $V$. splendidus have $59 \%$ DNA-DNA relatedness. High DNA-DNA relatedness between different species of the Vibrio core group has also been found (Baumann \& Baumann, 1977; Dorsch et al., 1992). For instance, strains of Vibrio harveyi and Vibrio campbellii have up to $74 \%$ DNA-DNA relatedness and very similar phenotypes, but they can be clearly distinguished by genomic fingerprinting techniques such as FAFLP and repetitive extragenic palindrome-PCR (Thompson et al., 2001; B. Gomez-Gil and others, unpublished). V. cyclitrophicus (Hedlund \& Staley, 2001) was reported to have a G+C content of $39 \mathrm{~mol} \%$, but our results clearly show that this bacterium has a $\mathrm{G}+\mathrm{C}$ content of $44 \cdot 2 \mathrm{~mol} \%$. Measurements of the $\mathrm{G}+\mathrm{C}$ content of DNA by renaturation methods, like that used by Hedlund \& Staley (2001), are prone to errors caused by low-quality DNA (i.e. fragmented DNA and/or DNA contaminated with proteins and/or RNA), which might influence the results significantly (Mesbah et al., 1989).

The three novel Vibrio species examined in this study share the main phenotypic and chemotaxonomic features of the genus Vibrio (Bertone et al., 1996; Farmer \& HickmanBrenner, 1992; Lambert et al., 1983). The three novel Vibrio species had several phenotypic features in common: the 23 isolates were Gram-negative, facultatively anaerobic, catalaseand oxidase-positive and showed prolific growth on thiosulphate/citrate/bile salts (TCBS) agar, forming yellow colonies (except strains LMG $21537^{\mathrm{T}}$ and LMG 13251, which formed green colonies). Isolates were motile by means of at least one polar flagellum, susceptible to 10 and $150 \mu \mathrm{g}$ O/129 (strain LMG 21523 was resistant to both concentrations) and did not grow in the absence of $\mathrm{NaCl}$. The predominant fatty acids (accounting for $>80 \%$ of the total cellular fatty acid composition) were summed feature 3 (comprising $16: 1 \omega 7 c$ and/or $15: 0$ iso $2-\mathrm{OH}$ ), 16:0, $18: 1 \omega 7 c, 14: 0$ and $12: 0$.

The three novel species fermented D-glucose and mannitol but not inositol or rhamnose. Strains of the novel 
species utilized $\alpha$-D-glucose, dextrin, glycogen, $N$-acetyl-Dglucosamine, D-fructose, maltose, D-trehalose, DL-lactic acid, succinic acid, L-alanyl glycine, L-asparagine, L-aspartic acid, L-glutamic acid, monomethyl succinate, glycyl L-aspartic acid, L-threonine, inosine and glycerol as sole carbon sources. None of the novel species utilized $N$-acetyl-Dgalactosamine, adonitol, D-arabitol, i-erythritol, L-fucose, $m$-inositol, $\alpha$-lactose, D-melibiose, D-raffinose, L-rhamnose, turanose, xylitol, citric acid, D-galactonic acid lactone, D-galacturonic acid, D-glucosaminic acid, $\gamma$-hydroxybutyric acid, $p$-hydroxyphenylacetic acid, itaconic acid, $\alpha$-ketobutyric acid, $\alpha$-ketovaleric acid, malonic acid, L-leucine, L-pyroglutamic acid, DL-carnitine, $\gamma$-aminobutyric acid, urocanic acid, phenylethylamine, 2-aminoethanol or 2,3-butanediol. Strains of the three species produced indole, alkaline phosphatase, esterase $\left(\mathrm{C}_{4}\right)$, esterase lipase $\left(\mathrm{C}_{8}\right)$ and naphtholAS-BI-phosphohydrolase but not lysine or ornithine decarboxylase, $\mathrm{H}_{2} \mathrm{~S}$, urease, cystine arylamidase, $\alpha$-galactosidase, $\beta$-glucuronidase, $\alpha$ - or $\beta$-glucosidase, $\alpha$-mannosidase or $\alpha$-fucosidase. The three novel species were non-luminescent, reduced nitrate and were methyl-red-positive (A46 isolates were methyl-red-negative). FAFLP groups A51 and A52/A53 were susceptible to polymixin B (300 U), tetracycline ( $30 \mu \mathrm{g}$ per disc) and chloramphenicol (30 $\mu$ g per disc), but were resistant to ampicillin ( $25 \mu \mathrm{g}$ per disc). None of the 23 isolates grew on 0 or $\geqslant 10.0 \% \mathrm{NaCl}$ or at $\geqslant 35{ }^{\circ} \mathrm{C}$. Additional phenotypical features found to be variable among the three novel Vibrio species are available as supplementary data in IJSEM Online.

Genomic and phenotypic evidence presented in this study clearly indicates that the 23 isolates should be accommodated in three novel Vibrio species. Although the novel species have the main phenotypic traits of the genus Vibrio, several useful differentiating features were found that distinguish them from known Vibrio species (available as supplementary material in IJSEM Online).

\section{Description of Vibrio kanaloae sp. nov.}

Vibrio kanaloae (ka.na.lo'a.e. N.L. gen. n. kanaloae of Kanaloa, the Hawaiian god of the sea and seamen).

Cells are slightly curved, $1 \mu \mathrm{m}$ wide by $2-3 \mu \mathrm{m}$ long and motile by at least one polar flagellum. They form translucent, convex, non-swarming, smooth, rounded colonies with entire margins; colonies are beige in colour and about $5 \mathrm{~mm}$ in diameter on TSA after $48 \mathrm{~h}$ incubation at $28{ }^{\circ} \mathrm{C}$. Strains form yellow, translucent, $5-10 \mathrm{~mm}$ colonies on TCBS agar. All strains ferment sucrose and arabinose but not sorbitol, melibiose or amygdalin. Cells grow at $4{ }^{\circ} \mathrm{C}$ but not in the absence of $\mathrm{NaCl}$. All strains utilize Tween 40, D-mannitol, sucrose, monomethyl succinate, $\alpha$-ketoglutaric acid, D-alanine, L-alanine, L-ornithine, L-proline, L-serine and L-threonine. None of the strains utilizes cellobiose, D-sorbitol, D-saccharic acid, sebacic acid, succinamic acid, hydroxy-L-proline, L-phenylalanine or DL- $\alpha$-glycerol phosphate. Strains produce leucine arylamidase, trypsin, tryptophan deaminase, acetoin and gelatinase, but not $\alpha$-chymotrypsin, $\alpha$-galactosidase, $\beta$-galactosidase or lysine. Arginine dihydrolase activity is variable, but is positive for the type strain. The major fatty acids are summed feature $3(39 \cdot 2 \pm 0 \cdot 2 \%$, comprising $16: 1 \omega 7 c$ and/or $15: 0$ iso $2-\mathrm{OH}), 16: 0(25 \cdot 6 \pm 1 \cdot 0 \%), 14: 0$ $(5 \cdot 0 \pm 0 \cdot 3 \%), 12: 0(4 \cdot 2 \pm 0 \cdot 1 \%), 18: 1 \omega 7 c(10 \cdot 2 \pm 1 \cdot 0 \%)$, summed feature $2(2 \cdot 1 \pm 0 \cdot 6 \%$, comprising $14: 03-\mathrm{OH}$ and/or $16: 1$ iso I and/or unidentified fatty acid with equivalent chain-length value of 10.928 and/or $12: 0$ ALDE), $12: 03-\mathrm{OH}(3 \cdot 4 \pm 0 \cdot 1 \%), 18: 0(1 \cdot 0 \pm 0 \cdot 1 \%)$ and $16: 03-\mathrm{OH}(0 \cdot 3 \pm 0 \cdot 1 \%)$. Additional phenotypical features are listed as supplementary material in IJSEM Online.

The type strain, strain LMG $20539^{\mathrm{T}}\left(=\mathrm{CAIM} 485^{\mathrm{T}}=\mathrm{INCO}\right.$ $191^{\mathrm{T}}$ ), was isolated from diseased oyster (Ostrea edulis) larvae in France. The $\mathrm{G}+\mathrm{C}$ content of the DNA of the type strain is $44 \cdot 5 \mathrm{~mol} \%$.

\section{Description of Vibrio pomeroyi sp. nov.}

Vibrio pomeroyi (po.me.roy'i. N.L. gen. n. pomeroyi of Pomeroy, in honour of the North American microbial ecologist L. R. Pomeroy).

Cells are slightly curved, $1 \mu \mathrm{m}$ wide by $2-3 \mu \mathrm{m}$ long and motile by at least one polar flagellum. They form translucent, convex, non-swarming, smooth, rounded colonies with entire margins; colonies are beige in colour and about $3 \mathrm{~mm}$ in diameter on TSA after $48 \mathrm{~h}$ incubation at $28{ }^{\circ} \mathrm{C}$. Strains (except LMG $20537^{\mathrm{T}}$ ) form yellow, translucent colonies on TCBS agar. Cells grow at $4{ }^{\circ} \mathrm{C}$ but not in the absence of $\mathrm{NaCl}$. All strains utilize D-galactose, cellobiose, monomethyl succinate, sucrose, glycyl L-glutamic acid, L-serine, L-threonine, inosine, uridine and thymidine. None of the strains utilizes $\alpha$-cyclodextrin, gentiobiose, $\alpha$-D-lactose lactulose, putrescine, formic acid, D-glucuronic acid, $\alpha$-hydroxybutyric acid, $\alpha$-ketoglutaric acid, quinic acid, D-saccharic acid, sebacic acid, succinamic acid, glucuronamide, L-histidine, hydroxyL-proline, L-leucine, L-phenylalanine, L-pyroglutamic acid, D-serine, DL-carnitine or DL- $\alpha$-glycerol phosphate. Strains produce $\beta$-galactosidase and acid phosphatase, but not lipase $\left(C_{14}\right)$, tryptophan deaminase or valine arylamidase. Arginine dihydrolase activity is variable, but is positive for the type strain. The major fatty acids are summed feature 3 $(32 \cdot 9 \pm 1 \cdot 6 \%), 16: 0(29 \cdot 2 \pm 1 \cdot 7 \%), 14: 0(10 \cdot 5 \pm 0 \cdot 4 \%)$, $12: 0 \quad(8 \cdot 9 \pm 1 \cdot 2 \%), \quad 18: 1 \omega 7 c \quad(7 \cdot 6 \pm 1 \cdot 8 \%)$, summed feature $2(4 \cdot 1 \pm 0 \cdot 6 \%), 12: 03-\mathrm{OH}(3 \cdot 9 \pm 0 \cdot 6 \%), 18: 0$ $(1 \cdot 6 \pm 0 \cdot 2 \%)$ and $16: 03-\mathrm{OH}(0 \cdot 7 \pm 0 \cdot 1 \%)$. Additional phenotypic features are available as supplementary material in IJSEM Online.

The type strain, LMG $20537^{\mathrm{T}}\left(=\right.$ CAIM $\left.578^{\mathrm{T}}=\operatorname{INCO~} 62^{\mathrm{T}}\right)$, was isolated from bivalve (Nodopecten nodosus) larvae in southern Brazil. The $\mathrm{G}+\mathrm{C}$ content of the DNA of the type strain is $44 \cdot 1 \mathrm{~mol} \%$. 


\section{Description of Vibrio chagasii sp. nov.}

Vibrio chagasii (cha.ga'si.i. N.L. gen. n. chagasii of Chagas, in honour of the Brazilian physician and microbiologist C. Chagas).

Cells are slightly curved, $1 \mu \mathrm{m}$ wide by $2-3 \mu \mathrm{m}$ long and motile by means of at least one polar flagellum. They form opaque, convex, non-swarming, smooth, rounded colonies with entire margins; colonies are dark beige in colour and 3-4 mm in diameter on TSA after $48 \mathrm{~h}$ incubation at $28^{\circ} \mathrm{C}$. Does not grow in the absence of $\mathrm{NaCl}$. All strains (except LMG 13251) form green, transparent colonies on TCBS agar. All strains utilize Tweens 40 and 80, cellobiose, L-alanine, D-mannitol, psicose and $\alpha$-ketoglutaric acid as sole carbon sources. None of the strains utilizes L-arabinose, methyl $\beta$-D-glucoside, $\alpha$-cyclodextrin, gentiobiose, $\alpha$-Dlactose, lactulose, putrescine, $\beta$-hydroxybutyric acid, S-saccharic acid, sebacic acid, L-ornithine or L-phenylalanine. Strains do not produce tryptophan deaminase The most abundant fatty acids are summed feature 3 $(38 \cdot 4 \pm 3 \cdot 5 \%), 16: 0(22 \cdot 4 \pm 3 \cdot 9 \%), 18: 1 \omega 7 c(9 \cdot 7 \pm 1 \cdot 6 \%)$, $14: 0(7 \cdot 2 \pm 3 \cdot 5 \%), 16: 0$ iso $(5 \cdot 2 \pm 2 \cdot 6 \%), 12: 0(3 \cdot 8 \pm 2 \cdot 0 \%)$, summed feature $2(3 \cdot 3 \pm 1 \cdot 3 \%), 12: 03-\mathrm{OH}(2 \cdot 7 \pm 1 \cdot 4 \%)$, $18: 0(1 \cdot 1 \pm 0 \cdot 5 \%), 14: 0$ iso $(1 \cdot 1 \pm 0 \cdot 7 \%), 15: 0(0 \cdot 6 \pm 0 \cdot 3 \%)$, $17: 0(0 \cdot 5 \pm 0 \cdot 3 \%)$ and $14: 0$ iso $3-\mathrm{OH}(0 \cdot 5 \pm 0 \cdot 3 \%)$. Additional phenotypic features are available as supplementary material in IJSEM Online.

The type strain, LMG $21353^{\mathrm{T}}\left(=\mathrm{CAIM} 431^{\mathrm{T}}=\mathrm{R}-3712^{\mathrm{T}}\right)$, was isolated from the gut of turbot larvae (Scophthalmus maximus) in Norway. The G $+\mathrm{C}$ content of the DNA of the type strain is $44 \cdot 5 \mathrm{~mol} \%$.

\section{ACKNOWLEDGEMENTS}

F. L. T. is the recipient of a PhD scholarship (no. 2008361/98-6) from Conselho Nacional de Desenvolvimento Científico e Tecnológico $(\mathrm{CNPq})$, Brazil. J. S. acknowledges grants from the Fund for Scientific Research (FWO), Belgium, and B.G.-G. acknowledges grants from CONACyT, Mexico.

\section{REFERENCES}

Acar, J. F. \& Goldstein, F. W. (1996). Disc susceptibility test. In Antibiotics in Laboratory Medicine, 4th edn, pp. 1-51. Edited by V. Lorian. Baltimore: Williams \& Wilkins.

Aiyar, S. E., Gaal, T. \& Gourse, R. L. (2002). rRNA promoter activity in the fast-growing bacterium Vibrio natriegens. J Bacteriol 184, 1349-1358.

Baumann, P. \& Baumann, L. (1977). Biology of the marine enterobacteria: genera Beneckea and Photobacterium. Annu Rev Microbiol 31, 39-61.

Baumann, P., Furniss, A. L. \& Lee, J. V. (1984). Genus I. Vibrio Pacini 1854, 411 $1 \mathrm{AL}$. In Bergey's Manual of Systematic Bacteriology, vol. 1, pp. 518-538. Edited by N. R. Krieg \& J. G. Holt. Baltimore: Williams \& Wilkins.

Bertone, S., Giacomini, M., Ruggiero, C., Piccarolo, C. \& Calegari, L. (1996). Automated systems for identification of heterotrophic marine bacteria on the basis of their fatty acid composition. Appl Environ Microbiol 62, 2122-2132.

Dorsch, M., Lane, D. \& Stackebrandt, E. (1992). Towards a phylogeny of the genus Vibrio based on $16 \mathrm{~S}$ rRNA sequences. Int $J$ Syst Bacteriol 42, 58-63.

Farmer, J. J., III \& Hickman-Brenner, F. W. (1992). The genera Vibrio and Photobacterium. In The Prokaryotes. A Handbook on the Biology of Bacteria: Ecophysiology, Isolation, Identification, and Applications, 2nd edn, pp. 2952-3011. Edited by A. Balows, H. G. Trüper, M. Dworkin, W. Harder \& K. H. Schleifer. Berlin: Springer.

Hedlund, B. P. \& Staley, J. T. (2001). Vibrio cyclotrophicus sp. nov., a polycyclic aromatic hydrocarbon (PAH)-degrading marine bacterium. Int J Syst Evol Microbiol 51, 61-66.

Huys, G., Vancanneyt, M., Coopman, R., Janssen, P., Falsen, E., Altwegg, M. \& Kersters, K. (1994). Cellular fatty acid composition as a chemotaxonomic marker for the differentiation of phenospecies and hybridization groups in the genus Aeromonas. Int J Syst Bacteriol 44, 651-658.

Jukes, T. H. \& Cantor, C. R. (1969). Evolution of protein molecules. In Mammalian Protein Metabolism, pp. 21-132. Edited by H. N. Munro. New York: Academic Press.

Lambert, M. A., Hickman-Brenner, F. W., Farmer, J. J., III \& Moss, C. W. (1983). Differentiation of Vibrionaceae species by their cellular fatty acid composition. Int J Syst Bacteriol 33, 777-792.

Macián, M. C., Garay, E., González-Candelas, F., Pujalte, M. J. \& Aznar, R. (2000). Ribotyping of Vibrio populations associated with cultured oysters (Ostrea edulis). Syst Appl Microbiol 23, 409-417.

Macián, M. C., Ludwig, W., Aznar, R., Grimont, P. A. D., Schleifer, K. H., Garay, E. \& Pujalte, M. J. (2001). Vibrio lentus sp. nov., isolated from Mediterranean oysters. Int J Syst Evol Microbiol 51, 1449-1456.

Mesbah, M., Premachandran, U. \& Whitman, W. B. (1989). Precise measurement of the $\mathrm{G}+\mathrm{C}$ content of deoxyribonucleic acid by highperformance liquid chromatography. Int J Syst Bacteriol 39, 159-167. Murray, R. G. E., Doetsch, R. N. \& Robinow, C. F. (1994). Determinative and cytological light microscopy. In Methods for General and Molecular Bacteriology, pp. 21-41. Edited by P. Gerhardt. Washington, DC: American Society for Microbiology.

Pearson, W. R. \& Lipman, D. J. (1988). Improved tools for biological sequence comparison. Proc Natl Acad Sci U S A 85, 2444-2448.

Pitcher, D. G., Saunders, N. A. \& Owen, R. J. (1989). Rapid extraction of bacterial genomic DNA with guanidium thiocyanate. Lett Appl Microbiol 8, 151-156.

Pujalte M.-J., Ortigosa, M., Urdaci, M.-C., Garay, E. \& Grimont, P. A. D. (1993). Vibrio mytili sp. nov., from mussels. Int J Syst Bacteriol 43, 358-362.

Saitou, N. \& Nei, M. (1987). The neighbor-joining method: a new method for reconstructing phylogenetic trees. Mol Biol Evol 4, 406425.

Sawabe, T., Thompson, F. L., Heyrman, J. \& 7 other authors (2002). Fluorescent amplified fragment length polymorphism and repetitive extragenic palindrome-PCR fingerprinting reveal host-specific genetic diversity of Vibrio halioticoli-like strains isolated from the gut of Japanese abalone. Appl Environ Microbiol 68, 4140-4144.

Sugumar, G., Nakai, T., Hirata, Y., Matsubara, D. \& Muroga, K. (1998). Vibrio splendidus biovar II as the causative agent of bacillary necrosis of Japanese oyster Crassostrea gigas larvae. Dis Aquat Organ 33, 111-118.

Thompson, F. L., Hoste, B., Vandemeulebroecke, K. \& Swings, J. (2001). Genomic diversity amongst Vibrio isolates from different sources determined by fluorescent amplified fragment length polymorphism. Syst Appl Microbiol 24, 520-538. 
Thompson, F. L., Hoste, B., Vandemeulebroecke, K., Engelbeen, K., Denys, R. \& Swings, J. (2002). Vibrio trachuri Iwamoto et al. 1995 is a junior synonym of Vibrio harveyi (Johnson and Shunk 1936) Baumann et al. 1981. Int J Syst Evol Microbiol 52, 973-976.

Vandamme, P., Segers, P., Ryll, M. \& 8 other authors (1998). Pelistega europaea gen. nov., sp. nov., a bacterium associated with respiratory disease in pigeons: taxonomic structure and phylogenetic allocation. Int J Syst Bacteriol 48, 431-440.
Verdonck, L., Grisez, L., Sweetman, E., Minkoff, G., Sorgeloos, P., Ollevier, F. \& Swings, J. (1997). Vibrios associated with routine productions of Brachionus plicatilis. Aquaculture 149, 203-214.

Willems, A., Doignon-Bourcier, F., Goris, J., Coopman, R., de Lajudie, P., De Vos, P. \& Gillis, M. (2001). DNA-DNA hybridization study of Bradyrhizobium strains. Int $J$ Syst Evol Microbiol 51, 1315-1322. 